Reprod. Nutr. Dévelop., 1980, 20 (3 A), 727-733.

\title{
Thermal induction of diploid gynogenesis and triploidy in the eggs of the rainbow trout (Salmo gairdneri Richardson)
}

\author{
par D. CHOURROUT
}

Laboratoire de Physiologie des Poissons, I.N.R.A., 78350 Jouy-en-Josas, France

Summary. Sporadic diploid gynogenetic fry resulted from fertilization with $\gamma$-irradiated sperm. Their frequency increased appreciably when thermal shock treatments, beginning during the first hour of development $\left(-0.4^{\circ} \mathrm{C}\right.$ lasting $6 \mathrm{hrs} 45 \mathrm{~min} ; 26-30^{\circ} \mathrm{C}$ lasting $10 \mathrm{~min}$ ), were used. When the eggs were fertilized with normal sperm, a good triploidization rate was induced by means of heat shocks (27-30 ${ }^{\circ} \mathrm{C}$ lasting $10 \mathrm{~min}$ ). It is supposed that the retention of the second polar body caused the gynogenetic diploidy observed.

\section{Introduction.}

Fertilization with $\gamma$-irradiated sperm is a good way, in salmonids, to obtain a large number of haploid embryos (Purdom, 1969 ; Chourrout et al., 1980) ; these embryos reach a late stage of organogenesis but generally die before, or immediately after, hatching.

Many works on amphibians and mammals show that viable gynogenetic progeny can be produced by artificial diploidization of the maternal gamete (retention of the second polar body or inhibition of the first cleavage) (Rostand, 1934), and several physical or chemical treatments have proved to be efficient (e.g. thermal shock, high hydrostatic pressure, antimitotics). When these eggs are fertilized with normal sperm, they produce triploid or teiraploid development.

Diploid gynogenesis was recently induced in several fish species by using cold shocks (more than $1 \mathrm{hr}$ at less than $4^{\circ} \mathrm{C}$ ) beginning a few minutes after fertilization with irradiated sperm (Romashov et al., 1963 ; Purdom, 1969 ; Nagy ef al., 1978). However, even with subzero temperatures, such treatments were not successful in salmonids (Lincoln ef al., 1974). Triploidy was induced in Gasterosteus aculeatus (Svarup, 1959) and in Tilapia aurea (Valenti, 1975) by heat shocks following normal fertilization.

Without thermal treatment, a small proportion of «spontaneous » gynogenetic diploid fry was usually reported. Stanley (1976) working on « spontaneous » gynogenetic diploidy in the grass carp, a very prolific species, obtained a sufficient number of fish to maintain a monosexual population. But the number of eggs spawned by a rainbow trout female is much smaller, and our prime objective is to use gynogenesis as a convenient tool for the rapid production of highly inbred strains; the level of inbreeding in those strains would depend greatly on the way in which diploidy 
is induced. These two reasons (lower prolificity and an unknown diploidization mechanism) led us to try to increase appreciably diploid gynogenesis, inhibiting a known post-fertilization stage.

In the present work, we used thermal shocks to induce gynogenesis and polyploidy in the rainbow trout. Three parameters were analyzed : temperature level, shock duration and time-course between fertilization and the onset of the treatment.

\section{Material and methods.}

The abdomen of each male trout was squeezed to remove the sperm which was mixed in a single flask, then distributed into three tubes and irradiated with 110 , 150 and $190 \gamma$-Krads, respectively, for $20 \mathrm{~min}$ (Chourrout ef al., 1980). After irradiation, the tubes of sperm were mixed again and kept at $4{ }^{\circ} \mathrm{C}$ until fertilization. The sperm used in the first experiment was collected from 2 males, homozygous for a dominant depigmentation gene (yellow phenotype) serving as a paternal marker.

We used only normal pigmented females (recessive homozygous at the same locus) which had been ovulating during the previous week. The eggs were mixed, drained and then divided into batches; an equal quantity of sperm (more than $1 \mu \mathrm{l} / \mathrm{egg}$ ) and an equal amount of a sperm diluent (saline solution with $\mathrm{pH} 9$ buffer) were mixed successively with the eggs which, after $15 \mathrm{~min}$, were introduced into a thermoregulated $\left(10^{\circ} \mathrm{C}\right)$ recirculating system for incubation. This instant was taken as development time zero.

The thermal shocks were characterized by the three following parameters : (i) temperature level $(\theta)$, (ii) shock duration (T), (iii) pre-shock duration at $10^{\circ} \mathrm{C}(t)$. A summary of the experimental design is given in table 1.

TABLE 1

Experimental design

\begin{tabular}{|c|c|c|c|c|c|c|c|}
\hline Exp. no. & $\hat{\sigma}$ & 9 & Sperm & Treatment & $\theta$ & $T$ & $t$ \\
\hline 1 & 2 & 3 & irrad. & \multicolumn{4}{|c|}{ no thermal shocks } \\
\hline 2 & 20 & 18 & irrad. & cold shocks & $+0.2^{\circ} \mathrm{C}$ & $2 \mathrm{~h}-24 \mathrm{~h}$ & $0-40 \mathrm{~min}$ \\
\hline 3 & 8 & 15 & irrad. & cold shocks & $-0.4{ }^{\circ} \mathrm{C}$ & $6 \mathrm{~h} 45$ & $0-30 \mathrm{~min}$ \\
\hline 4 & 15 & 6 & irrad. & heat shocks & $23-30 \circ \mathrm{C}$ & $10 \mathrm{~min}$ & $0-80 \mathrm{~min}$ \\
\hline 5 & 12 & 15 & normal & heat shocks & $27-30 \circ \mathrm{C}$ & $10 \mathrm{~min}$ & $0-70 \mathrm{~min}$ \\
\hline
\end{tabular}

Activation rate. - The rate of live embryos was computed in each baich between days 20 and $25\left(D_{20}\right.$ and $\left.D_{25}\right)$ (eyed-stage), and the eggs immediately replaced in the incubation system.

Hatching rate. - At $D_{50}$, the number of hatched fry was determined; the fingerlings were regrouped into a single batch in experiments 1,2 and 3 and into two batches in experiment 4 (4a:23-26 $\left.{ }^{\circ} \mathrm{C} ; 4 b: 27-30^{\circ} \mathrm{C}\right)$. 
Determination of ploidy. - A sample of 3-month old fish was taken from each batch for karyological examination. They were kept swimming in 1 p. 1000 colchicin for $20 \mathrm{hrs}$ and then killed. A piece of the gills was submitted to a 20-min hypotonic shock $(2$ p. $1000 \mathrm{NaCl}$ ). The slides were prepared and covered according to Jaylet's method (1971), except for the Giemsa staining (diluted $5 X$ in 10 p. $100 \mathrm{Na}_{2} \mathrm{HPO}_{4}$ ).

\section{Results.}

1. «Spontaneous 》 diploidy (experiment 1, table 2). - Most of the embryos belonging to the batch fertilized with irradiated sperm presented the haploid syndrome. Only a very low proportion (3 p. 1000 ) hatched and gave normal diploid fingerlings. They were of maternal phenotype (pigmented body), whereas all the hatched control fry were yellow.

TABLE 2

Experiment $1:$ « Spontaneous » diploidy

\begin{tabular}{lcc}
\hline & $\begin{array}{c}\text { Irradiated } \\
\text { sperm }\end{array}$ & $\begin{array}{c}\text { Control } \\
\text { sperm }\end{array}$ \\
\hline No. of eggs. $\ldots \ldots \ldots \ldots \ldots \ldots \ldots$ & 5493 & 768 \\
\hline p. 100 of live embryos $D_{25} \ldots \ldots \ldots \ldots$ & 42.7 & 72.4 \\
\hline p. 100 of viable fry $D_{50} \ldots \ldots \ldots \ldots$ & 0.14 & 70.7 \\
\hline
\end{tabular}
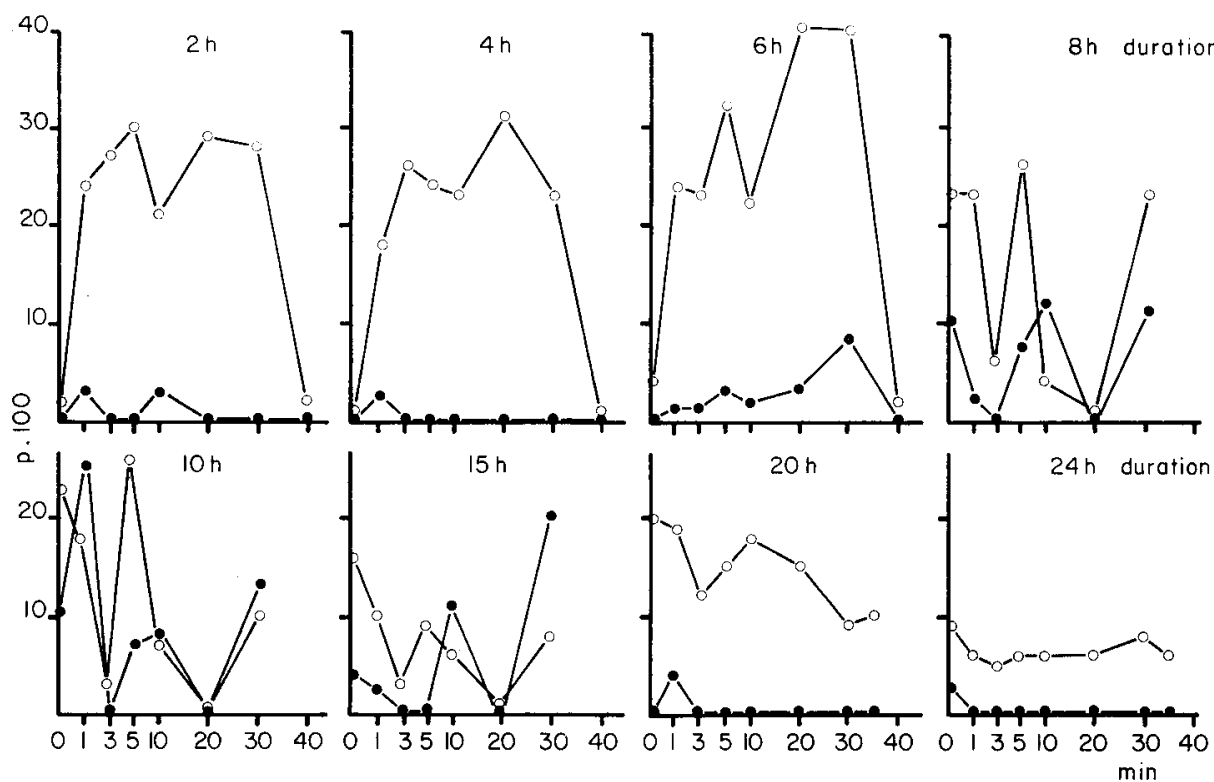

FIG. 1. - Cold shocks at $0.2^{\circ} \mathrm{C}$. 느 : 0 : Activation rate 》 at Day 25 : preshock duration at $10^{\circ} \mathrm{C}$ in relation to the percentage of eggs with a live embryo. - : - Diploidization rate " at Day 50 : preshock duration at $10^{\circ} \mathrm{C}$ in relation to the percentage of live embryos at Day 25 giving a viable fingerling. 
2. Cold shock at $+0,2^{\circ} \mathrm{C}$ (experiment 2, fig. 1).

a) Embryonic eyed-stage. - Generally, the activation rate computed at $D_{25}$ decreased with the shock duration and differed considerably in terms of the parameter $t$.

b) Viable fry. - Shock durations of 6 to $15 \mathrm{hrs}$ induced an appreciable increase in the hatching rate as compared to the results obtained in the control batch. The $t$ values varied widely again. The proportion of hatched fry to the number of live embryos at $D_{25}$ reached 25 p. 100 in the best case $(T=10 \mathrm{hrs} ; t=1 \mathrm{~min})$. The 20 fingerlings analyzed at 3 months proved to be diploid.

3. Cold shock at $-0.4{ }^{\circ} \mathrm{C}$ (experiment 3 , table 3). - The use of a lower temperature did not disturb the activation rate; good hatching rates were obtained, especially for $t=0.1$ and $10 \mathrm{~min}$. All the metaphases were diploid (20 fingerlings). A small number of twisted fingerlings (about 5 p. 100) was recorded at hatching time.

TABLE 3

Experiment 3. Cold shocks at $-0.4{ }^{\circ} \mathrm{C}$ ( 5 p. 100 glycerol solution)

\begin{tabular}{cccc}
\hline$f(\min )$ & No. of eggs & $\begin{array}{c}\text { Activation rate } \\
\mathrm{D}_{25}(\mathrm{p} .100)\end{array}$ & $\begin{array}{c}\text { Viable hatched } \\
\text { fry } \mathrm{D}_{50} \\
\text { p. } 100\end{array}$ \\
\hline & & & \\
0 & 988 & 25 & $9.2(91)$ \\
1 & 1055 & 18 & $6.8(69)$ \\
10 & 1098 & 38 & $9.1(100)$ \\
30 & 1064 & 38 & $2.0(21)$ \\
no shock & 1046 & 42 & $0.2(2)$ \\
\hline
\end{tabular}

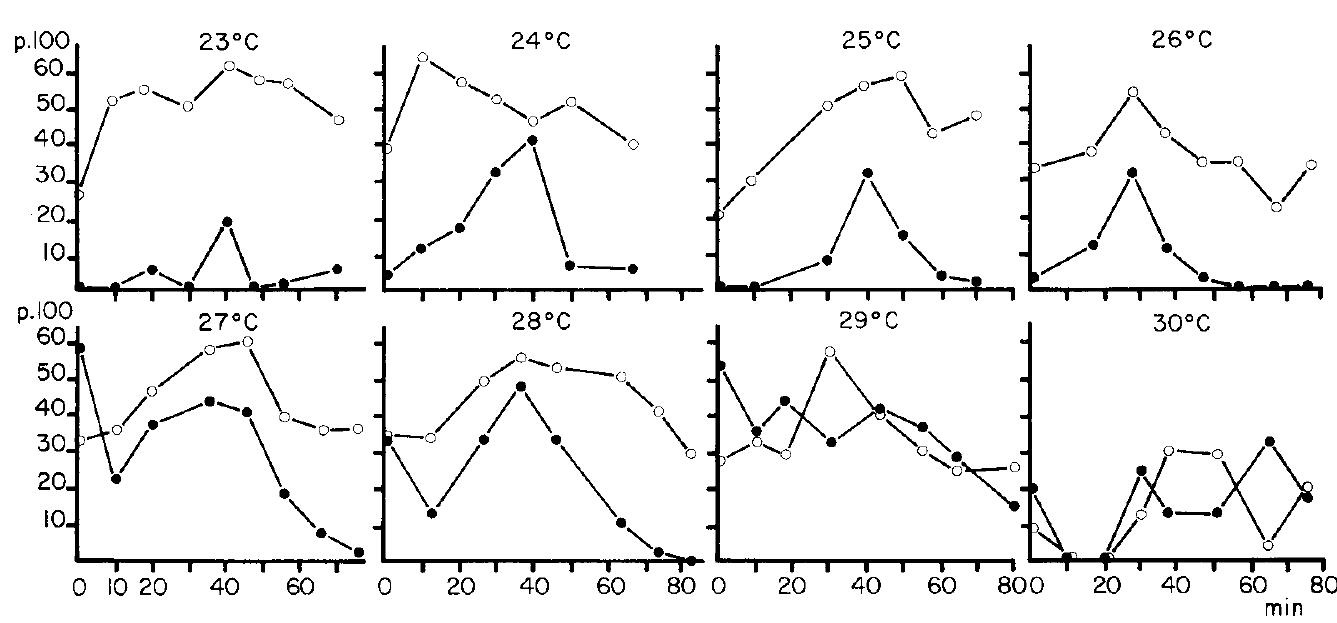

FIG. 2. - Heat shocks at 23 to $30^{\circ} \mathrm{C}$.

$\because \_$: 
4. Heat shocks at $23-30^{\circ} \mathrm{C}$ (experiment 4, fig. 2).

a) Embryonic eyed-stage. - The activation rate strongly decreased above $29^{\circ} \mathrm{C}$ and varied less in terms of $t$ than in the cold-shock experiments;

b) Viable fry. - For computations at $D_{50}$, we only considered the normal fingerlings. In fact, most of the batches contained variable proportions (around 15 p. 100), of twisted animals that died more or less rapidly. The heat shocks proved to be efficient for all tested temperatures; however, the hatching rate reached higher values at and above $26^{\circ} \mathrm{C}$. The lower temperatures were applied for about $40 \mathrm{~min}$, whereas good hatching rates were obtained with the higher temperatures 30 to 50 min after, or immediately after, fertilization. The 40 fingerlings analyzed (20 in $4 a$ and 20 in $4 b$ ) were diploid.

5. Heat shocks (normal sperm) at $27-30^{\circ} \mathrm{C}$ (experiment 5). - For technical reasons affecting this experiment, we had to regroup all the batches (without computation) before hatching time. We analyzed a sample of 183 -month old fingerlings : 9 were triploid (fig. 3) and 9 were diploid. The initial number of eggs in the batches was nearly constant, so we considered the 50 p. 100 triploidization as a rough estimate of the mean efficiency of all the treatments tested; those treatments, however, probably differed widely in their individual effectiveness, as evidenced by our gynogenetic experiments.

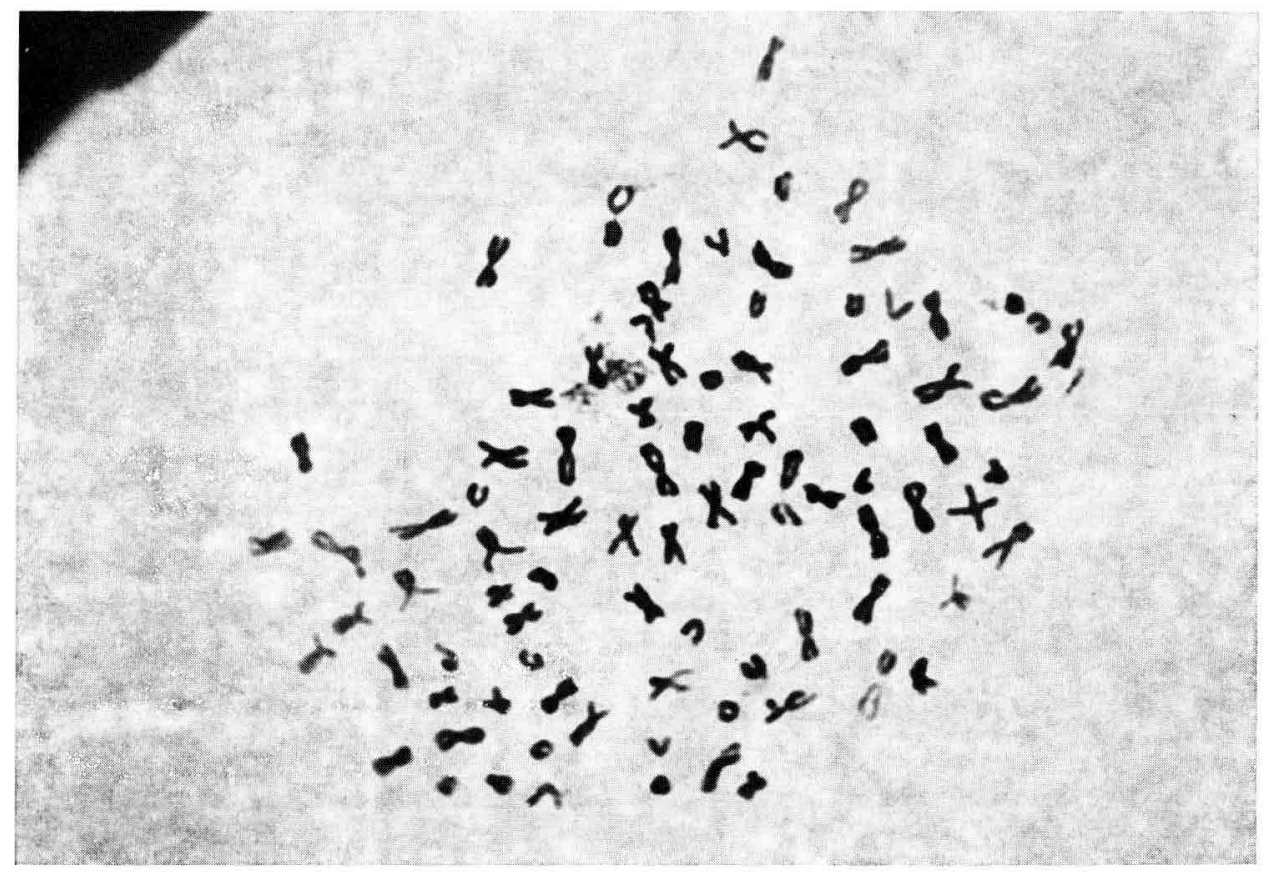

FIG. 3. - Triploid metaphase $(3 n=90)$. 


\section{Discussion and conclusions.}

Although it does not prove that the paternal genome was completely extruded, the black phenotype of the fingerlings obtained in experiment 1 (after irradiation) is a good argument in favor of their gynogenetic origin. A small proportion of diploid ovules is frequently observed in amphibian spawns. In this study, we could not determine which mechanism was responsible for «spontaneous" diploidy.

The $0{ }^{\circ} \mathrm{C}$ cold shocks applied for the first $30 \mathrm{~min}$ of development, and lasting more than $6 \mathrm{hrs}$, increased the hatching rate. However, salmonid eggs seemed to be less responsive to that type of treatment than the eggs of other fish (Purdom, 1969; Nagy ef al., 1978). The large variations found at the onset of the shocks might result from the small number of eggs in each batch, and must be investigated in more detail.

The results of subzero cold shocks indicate that it is necessary to thoroughly test these types of treatments : they have been described as inefficient up to 4 hrs (Lincoln et al., 1974), but are probably enough to produce a large number of diploid gynogenomes.

The eggs showed considerable response to hot temperatures. Some authors advise the induction of diploidy using other treatments like cold or hyperbare shock that provoke a reversible and more specific disruption of the microtubular spindle. In the present study, the efficient temperatures were relatively low as compared to those used on other animals (Jaylet and Ferrier, 1978), and so the problem may be different. Although we found fewer abnormal hatched fry in experiment 3 , the occurrence of twisted fingerlings in the heat shock experiment could be partially attributed to a strong increase in inbreeding (Aulstad and Kittelsen, 1971 ; Kincaid, 1976).

The diploidy was probably due to retention of the second polar body because the same treatments, applied after fertilization with non-irradiated sperm, gave a high rate of triploidization. With such a mechanism, we may expect a higher rate of homozygosity than with self-fertilization (Jalabert et al., 1975).

If, according to Thorgaard (1977) and Okada et al. (1979), the female is the homogametic sex in the rainbow trout, gynogenesis could be a way of producing monosexual female populations.

Reçu en septembre 1979.

Accepté en novembre 1979.

Résumé. Un petit nombre d'alevins gynogénétiques diploïdes résulte d'une fécondation par du sperme traité aux rayons $\gamma$. Leur taux est sensiblement augmenté lorsqu'on applique aux oufs différents chocs thermiques au cours de la première heure de leur développement $\left(-0.4^{\circ} \mathrm{C}\right.$, durée $6 \mathrm{~h} 45 ; 26-30^{\circ} \mathrm{C}$, durée $\left.10 \mathrm{mn}\right)$.

De la même façon, des chocs chauds similaires $\left(27-30^{\circ} \mathrm{C}\right.$, durée $10 \mathrm{~min}$ ) suivant une fécondation par du sperme normal ont induit un taux de triplö̈disation élevé ; par conséquent le mécanisme de restauration de la diploïdie chez les gynogénétiques était probablement la rétention du $2^{\mathrm{e}}$ globule polaire.

\section{References}

AULSTAD D., KITTELSEN A., 1971. Abnormal body curvatures of rainbow trout (Salmo gairdneri) inbred fry. J. Fish Res. Bd. Can., 28, 1918-1920. 
CHOURROUT D., CHEVASSUS B., HERIOUX F., 1980. Analysis of an Hertwig effect in the rainbow trout (Salmo gairdneri Richardson) after fertilization with $\gamma$-irradiated sperm. Reprod. Nutr. Dévelop., 20, 719-726.

JALABERT B., BILLARD R., CHEVASSUS B., 1975. Preliminary experiments on sex control in trout ; production of sterile fishes and simultaneous self-fertilizable hermaphrodites. Ann. Biol. anim. Bioch. Biophys., 15, 19-28.

JAYLET A., 1971. Création d'une lignée homozygote pour une translocation réciproque chez l'Amphibien Pleurodeles walliti. Chromosoma (Berl.), 34, 383-423.

JAYLET A., FERRIER V., 1978. Experimental gynogenesis in the Newt species Pleurodeles waltlii and P. poireti. Chromosoma, 69, 65-80.

KINCAID H. L., 1976. Inbreeding in rainbow trout (Salmo gairdneri). J. Fish. Res. Bd. Can., 33, 24202426.

LINCOLN R. F., AULSTAD D., GRAMMELTVEDT A., 1974. Attempted triploid induction in Atlantic salmon (Salmo salar) using cold shocks. Aquaculture, 4, 287-297.

NAGY A., RAJKI K., HORVATH L., CSANYI V., 1978. Investigation on carp Cyrpinus carpio L. gynogenesis. J. Fish Biol., 13, 215-224.

OKADA H., MATUMOTO H., YAMAZAKI F., 1979. Functional masculinization of genetic females in rainbow trout. Jap. Soc. Sci. Fish., 45, 413-419.

PURDOM C. E., 1969. Radiation-induced gynogenesis and androgenesis in fish. Heridity, 24, 431-444.

ROMASHOV D. D., NIKOLYUKIN N. I., BELYAEVA V. N., TIMOFEEVA N. A., 1963. Possibilities of producing diploid radiation-induced gynogenesis in sturgeons. Radiobiologiya, 3, 104-109 (transl. from Russ., Radiobiology, 3, 145-154.

ROSTAND J., 1934. Gynogenèse du crapaud par refroidissement de l'œuf. C. R. Soc. Biol., 115, $1680-1681$.

STANLEY J. G., 1976. A review of methods for obtaining monosex fish and progress report on production of monosex white amur. J. Aqu. Plant. Manag., 14, 68-70.

SVARUP H., 1959. Production of triploidy in Gasterosteus aculeatus. J. Genetics, 56, 129-142.

THORGAARD G. H., 1977. Heteromorphic sex chromosomes in male rainbow trout. Sciences, 196, 900-902.

VALENTI R. F., 1975. Induced polyploidy in Tilapia aurea (Steindachner) by means of temperature shock treaiment. J. Fish Biol., 7, 519-528. 